\title{
Enhancing the quality of decisions by administrators: A framework for identifying, classifying and engaging primary school stakeholders in Harare, Zimbabwe
}

\author{
Sharon Kwaramba and Stanley Murairwa \\ College of Business, Peace, Leadership and Governance, Africa University, Zimbabwe
}

\begin{abstract}
The article identified and classified the primary school stakeholders in Harare, Zimbabwe. The research used a case study and literature analysis results to develop a framework for analysing and classifying primary school stakeholders for enhancing the quality of the decisions by the administrators. The research collected both primary and secondary data from WhatsApp groups of Harare primary school instructors/teachers and parents/guardian sand the literature for analysis. The Voluntary sampling design was used to select the respondents. The research used data that was gathered from forty-five journal articles and sixty primary schoolteachers/instructors and parents/guardians. The research found that a successful implementation of the primary school stakeholder analysis makes the stakeholder identification and classification processes very simple and easy. There was significant a relationship between the primary school and its stakeholders but there was also challenges. This research developed the Stakeholder Identification, classification and Engagement (SICE) framework for identifying, classifying and engaging primary school stakeholders.
\end{abstract}

Key words: Zimbabwe Primary Schools, Primary school Stakeholders, Stakeholder Analysis, Stakeholder Classification, stakeholder engagement.

JEL: $\quad \mathrm{I} 2, \mathrm{I} 21$

Paper Classification: Research Paper

\section{INTRODUCTION}

A project is considered to have been successfully implemented when most of the stakeholders have been satisfied with the final deliverable. The evaluation requirement points to the demand at all cost for the involvement of all the stakeholders in the day to day running of primary school operations. The graduates from these schools will have the skills that meet the labour market requirements $(\mathrm{OECD}, 2017)$ if all the relevant stakeholders are participating in the service delivery process. According to Murairwa (2018) and Alves, Mainardes and Raposo(2010), the education sector in developing economies should be reviewed in order to evaluate its contribution to the overall economic development of the country. The researchers further stated that there was the need to identify the key stakeholders of the primary school. A stakeholders' engagement process is critical for the institutions to remain viable in unstable economic environment (Deloitte \& Touche, 2014) such as the current Disruptive Volatility, Uncertainty, Complexity And Ambiguity (DVUCA) global world. Globally, the schools' relationship engagements with stakeholders have been practiced in which positive relationships have resulted in interesting gains whilst the poor relationships have failed to achieve the purported goals. The administrators should possess knowledge and an understanding of all external and internal stakeholders (Boyce, 2020; Compliance Prime, 2019)in order to culture sustainable relationships that foster the achievement of primary school objectives. The relationship with the stakeholders aim to garner the support that helps the primary school to achieve its mission, goal, objectives and vision. Murairwa (2018) identified and discussed the stakeholders in relation to their contributions to the primary school education systems. The researcher stated that for the primary school to achieve continuous education quality enhancement, there is need for holistic participation of all the stakeholders.

According to Murairwa (2018), the list of the stakeholders was not exhaustive but the process management to identify the most important stakeholders for continuous education quality enhancement process. The stakeholder engagement connects the school's strategies with its stakeholders so that the results speak into the expectations of all the education stakeholders (Deloitte \& Touche, 2014). The offering of acceptable quality of education is a mammoth task that requires the collaboration of all the stakeholders of the primary schools. The stakeholders are the beneficiaries of the outputs from the school (Murairwa, 2018). Epstein, et al.(2002) defined a stakeholder as anybody who can affect or is affected by an institution, a strategy or a project. Stakeholders have the power to impact on the education or a project in some way (Sheridan, 2013). A school is an institution where formal learning or education is provided (Nyatuka, 2020). UNESCO (2017) defined educational institutions as entities that provide instructional services to individuals or learning-related services to individuals and other institutions. According to Abubakari and Al-hassan(2016), a school is a place (such as pre-schools, childcare, primary or elementary schools, 
secondary high schools, colleges and universities) where people of different ages gain an education. A school is an institution that offers education or learning service to children (Byerengo \& Onyango, 2021).In this article, a primary school is a place where primary education is provided. Baker (2018) and Christenson (2005) defined a good relationship as a cooperative relationship, association of mutual benefit as well as a positive sum gain from the cooperation. Sheridan (2013) classified a solid relationship as a strong connection and partnership between institutions. However, not everyone is a primary school stakeholder, the common examples of primary school stakeholders include churches, politicians, local business people, youth organizations, civil society, communities, parents, instructors/teachers, researchers and administrators, amongst many others who influence the creative and innovative decisions of the primary schools.

\section{Objectives}

The objectives of this research were to assess the perceptions of the Harare instructors/teachers and parents on the importance ofthe primary school to have a good relationship with its stakeholders; evaluate the levels of identification, classification and engagement of the primary school stakeholders; appraise the primary school stakeholders; and develop a primary school Stakeholders'Identification, Classification and Engagement (SICE) framework in Zimbabwe.

\section{LITERATURE REVIEW}

A number of researchers such as Wojrwnik-Filipkoska and Wegrzyn(2019), Murairwa (2018)and Aapaoja and Haapasalo(2014) identified the stakeholders of the school. Some of the researchers such as Williams(2017) referred to the stakeholder theory by Freeman(1984)as the origin of the stakeholder ranalysis, identification and management when responding to Stanford Research Institute that had introduced the notion that the shareholders were not the only important group to the institution. According to Parmar et al. (2010), stakeholder theory emerged as a new narrative to understand and remedy three inter-connected business challenges; the problem of (a) understanding how value is created and traded, (b) associating ethics and capitalism, and (c) assisting company managers think about management in order to deal with the first two business challenges. The collaboration between the school and its stakeholders addresses quiet easily the three stated business challenges (Parmar, et al., 2010).

Oleksiv and Shpak (2012) proposed an institution stakeholder analysis model. PHAST (2020) presented the Influence/Importance matrix for analysing the stakeholders of the institution. The Influence/Importance matrix with Importance (on the $x$-axis) and Influence (on the $y$-axis)has four quadrants and these are High/High, High/Low, Low/Low and Low/High. Aapaoja andHaapasalo(2014) discussed the stakeholder impact matrix that can be used for stakeholder analysis. The stakeholder impact matrix on the impact level and probability has four quadrants, namely, key players, keep satisfied, minimal effort and keep informed. The last stage of the stakeholder analysis model involves creating or modifying university policies and the ranking of priorities in accordance with stakeholders' interests (Seres, Tumbas, Maric, \& Pavlicevic, 2019). Table 1 shows some of the stakeholders identified for different institutions that may act as a guide for identifying, classifying and engaging the stakeholders of a school.

Table 1: Literature Survey of the Stakeholders of the Institution

\begin{tabular}{|c|c|}
\hline Research Study & Identified Stakeholders \\
\hline $\begin{array}{c}\text { Aapaoja and } \\
\text { Haapasalo(2014) }\end{array}$ & $\begin{array}{l}\text { Primary; key supporting; tertiary; and extended } \\
\text { stakeholders. }\end{array}$ \\
\hline $\begin{array}{l}\text { Benneworth and } \\
\text { Osborne(2015) }\end{array}$ & $\begin{array}{l}\text { Students; teachers; researchers; staff; regulators; } \\
\text { public policy makers; donors; banks; joint venture } \\
\text { partners; suppliers; media; and local community. }\end{array}$ \\
\hline $\begin{array}{c}\text { Boyce (2020), } \\
\text { PHAST (2020) and } \\
\text { Compliance Prime } \\
(2019) \\
\end{array}$ & $\begin{array}{l}\text { Internal (managers, owners and workers); and } \\
\text { External (customers, creditors, government, local } \\
\text { communities, customers) }\end{array}$ \\
\hline CIPS (2020) & $\begin{array}{c}\text { Internal (managers and employees); External } \\
\text { (government, regulatory bodies, community, } \\
\text { pressure groups; and Connected (suppliers, } \\
\text { customers, funders) } \\
\end{array}$ \\
\hline $\begin{array}{l}\text { Khanyile and Green } \\
\text { (2016) and Paine } \\
\text { (2009) }\end{array}$ & $\begin{array}{l}\text { Students; academics; government; countries; } \\
\text { embassies; business; private sector; donors; } \\
\text { sponsors; and subject matter experts. }\end{array}$ \\
\hline Murairwa (2018) & $\begin{array}{l}\text { Learners; instructors/lecturers; community; parents; } \\
\text { staff members; non-governmental organisations; } \\
\text { government; local authority; alumni; families; local } \\
\text { business people; elected officials; learners' elected } \\
\text { management; administrators; advocacy groups; } \\
\text { media houses; industry; financial institutions; } \\
\text { farmers; religious institutions; youth organisations; } \\
\text { and other education institutions. }\end{array}$ \\
\hline $\begin{array}{l}\text { Oleksiv and } \\
\text { Shpak(2012) }\end{array}$ & $\begin{array}{l}\text { Managers; shareholders; physicians; state } \\
\text { authorities; employees; suppliers; potential } \\
\text { creditors; and patients. }\end{array}$ \\
\hline Pinheiro(2015) & $\begin{array}{c}\text { Professional oligarchy; scientific community; } \\
\text { unionised lecturers; and private sector academics. }\end{array}$ \\
\hline $\begin{array}{l}\text { Seres, Tumbas, Maric } \\
\text { and Pavlicevic (2019) } \\
\text { and Slaba(2015) }\end{array}$ & $\begin{array}{l}\text { Accreditation commission; alumni; communities; } \\
\text { competitors; current students; donors and grant } \\
\text { organizations; employers; faculties and employees; } \\
\text { government authorities; high schools; local } \\
\text { government; management; marketing and public } \\
\text { relations departments; media; ministry of education; } \\
\text { parents; and prospective students. }\end{array}$ \\
\hline Singh (2021) & $\begin{array}{l}\text { Salience model: Power (authority and influence); } \\
\text { legitimacy (legally and morally); and urgency. }\end{array}$ \\
\hline $\begin{array}{c}\text { Wojewnik- } \\
\text { Filipkowska and } \\
\text { Wegrzyn(2019) }\end{array}$ & $\begin{array}{l}\text { Sponsor; lenders; investors; agencies; multilateral } \\
\text { institutions; contractor; supplier; operator; ecologist; } \\
\text { media; purchaser; unions; regulator; and grantor. }\end{array}$ \\
\hline
\end{tabular}

Slaba (2015) conducted a literature survey to identify the stakeholder groups of the Czech Republic's private and public universities. The researcher discovered that most of the researchers (Mainardes, Alves, \& Raposo, 2013; 2010; Maric, 2013; Mainardes, Raposo, \& Alves, 2012; Miroiu \& Andreescu, 2010) found students, community and government as the common stakeholder groups of the universities. The stakeholder identification is a significant phase in enlisting the assistance of valuable stakeholders and leveraging on their knowledge and wisdom in running the institution, gain alignment among them on goals and plans and to help address procedure conflicts (Product Plan, 2020). Aapaoja and Haapasalo(2014) proposed a framework for identifying and 
classifying the business stakeholders. The framework identified four stakeholder categories (Aapaoja \& Haapasalo, 2014). On the other hand, Wojewnik-Filipkowska and Wegrzyn(2019) identified the three types (legitimacy, urgency and power) and fourteen categories (see Table 1) of the stakeholders.

Murairwa (2018) identified twenty-two groups of key education stakeholders (see Table 1) who can further be grouped into primary and secondary categories. Pinheiro(2015) discussed four types of internal stakeholders in Brazil's higher education and these are professional oligarchy, scientific community, unionised lecturers and private sector academics. The stakeholder identification is the first step in stakeholder analysis and a number of researchers have written on the approach. Gudavajhala(2017) discussed five stakeholder analysis models and these are power versus interest, influence-impact, power-influence, importanceinfluence and salience models. Most researches (Lienert, 2020; Product Plan, 2020; Liang, Yu, \& Guo, 2017; Schmeer, 2016; McDonald, 2016) refer to brainstorming as the first step in stakeholder identification and the second step is grouping the stakeholders using mind maps or Venn maps or graph theory and the third step is reflecting on the diagrams to see if any critical stakeholder has been omitted. A Venn diagram or mind map is presented by Benneworth and Osborne (2015).Liang, Yu and Guo(2017) classified stakeholders into five major categories through clustering approach of the thirteen identified major stakeholders. The five clusters found by Liang, $\mathrm{Yu}$ and Guo(2017) are end-user, construction, consultation and service, finance and administration.

According to Freeman(2010), the "grand" father of stakeholder theory, a stakeholder is any individual (or group) who can be affected or is affected by the implementation and achievement of the institution's objectives. The Stakeholder theory and/or stakeholder management has, for some time, been a prominent issue in Social Sciences, mostly but not exclusively within the business management literature (Schwartzman, Pinheiro, \& Pillay, 2015). In institutions, attention has been paid mostly to the strategic significance attributed to ethical principles like trust, trustworthiness, and cooperativeness as sources of sustainable competitive advantages (Jones \& Wicks, 1999). Within the management literature, stakeholder theory has increased in popularity in part due to its emphasis on explaining and predicting how an institution functions with respect to the relationships and influences existing in its surrounding environments (Rawley, 1997) and also because of its descriptive accuracy, instrumental power and normative validity (UpCounsel, 2021; Milosevic, Donaldson, \& Preston, 2019; Mishra \& Mishra, 2013; Donaldson \& Preston, 1995). The theory is concerned with the nature of these relationships in terms of processes as well as outcomes both for the primary school and its stakeholders. The interests of all legitimate primary school stakeholders, since the theory is not interested in the nonlegitimate (others), have intrinsic value and no set of interests is assumed to dominate the others(Donaldson \& Preston,
1995). At its core, the theory sheds light on managerial soft and hard creative and innovative decision-making processes.

\section{Stakeholder selection process}

The stakeholders selection and involvement is an important role in business success (Hujainah, Bakar, Al-haimi, \& Abdulgabber, 2018). The selection of the stakeholders is critical in the overall business stakeholder engagement process(Land, Macura, Bernes, \& Johansson, 2017). A database facilitates the identification and selection of the stakeholders (BeWater, 2017).According to Huntley(2021), the increasing prevalent of stakeholder management, consultation and engagement was as a result of the recognition of the importance of the stakeholders' participation by most institutions. Thus, the contribution of the stakeholder engagement to the growth of the primary school is undebatable. Land, Macura, Bernes and Johansson(2017) identified five steps for stakeholder engagement in prioritisation and planning of environmental planning synthesis and these are stakeholder identification, policy identification and practice relevant topics, framing and prioritisation of review questions, establishment of the specific scope of the review and the public review of the draft review protocol. The selection of the stakeholders involves stakeholder analysis process with three distinctive phases, namely, stakeholder identification, prioritisation and understanding (Mendelow, 1981). The terms of the stakeholder analysis depend on the stakeholder engagement process that focuses on communication that involves three stages; stakeholder mapping(Mainardes, Alves, \& Raposo, 2012), management (Venturelli, Cosma, \& Leopizzi, 2018; Lim \& Greenwood, 2017)and engagement(Fasan \& Mio, 2017; Strand \& Freeman, 2015).

\section{Research Gap}

Currently, many learning institutions do not undertake a formal analysis of the stakeholders' interests and thus, the process of identifying the learning institution stakeholders may need to be developed from scratch(Mainardes, Alves, \& Raposo, 2010).Most of the accessed recent researches(CIPS, 2020; Wojewnik-Filipkowska \& Wegrzyn, 2019; Venturelli, Cosma, \& Leopizzi, 2018; Fasan \& Mio, 2017; Land, Macura, Bernes, \& Johansson, 2017) on the study of the stakeholders focused on non-educational institutions with the exception of Murairwa (2018) andKhanyile and Green(2016). Therefore, there is need for more studies on the Identification, Classification and Engagement (ICE) of the primary school stakeholders in order to improve the quality of the creative and innovative decisions that are made by the administrators.

\section{METHODOLOGY}

The research employed a traditional or narrative literature review as discussed by Green, Johnson and Adams(2006). A mixed-methods research design was applied in which both qualitative and quantitative data were gathered from 45 published journal articles and from 60 Harare primary school instructors/teachers and parents. The researcher published the 
intent to conduct a research on the Harare primary school instructors/teachers WhatsApp group. The WhatsApp group had 216 teachers/instructors. Each instructor/teacher was in a WhatsApp group with approximately 41 parents. Therefore, the estimated number of parents was 8856 at an average primary school classsize of 41 learners/pupils. This give an estimated population size of 9072 teachers and parents for this research. A questionnaire was designed and uploaded on internet and its internet-link was shared through WhatsApp groups. The researcher requested the instructors/teachers to send the questionnaire internet-link to parents in their WhatsApp groups. The instructors/teachers and parents who were willing to participate in the research completed the questionnaires. Thus, the Voluntary sampling design (Murairwa, 2015) was applied to select the respondents for this research. The advantage of the Voluntary sampling design (Murairwa, 2015)is that all the volunteered participants wilfully complete the research questions. The first sixtyfully completed questionnaires that were received from instructors/teachers and parents of Harare primary schools were considered as the sample for this research.

The research collected data on primary school Stakeholder Identification, Classification and Engagement (SICE)as presented in Figure 1.

\section{Independent variables}

\section{Dependent Variable}

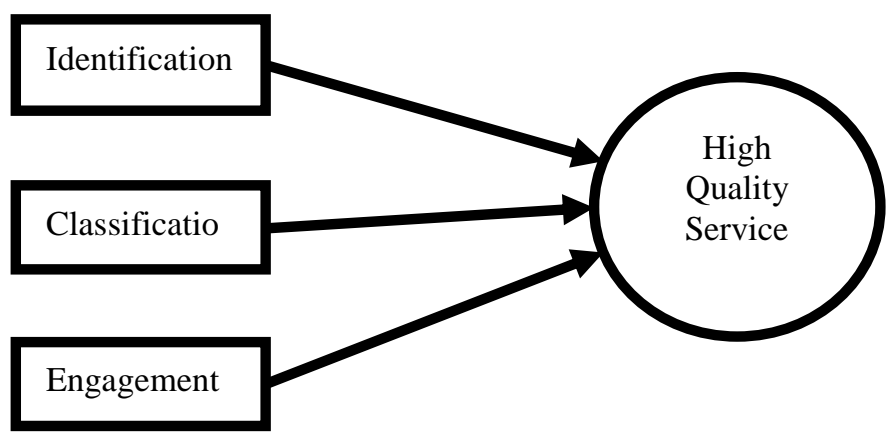

Figure 1: Research Conceptual Framework

The researcher collected both primary and secondary qualitative and quantitative data for the research. The research collected secondary data from literature for analysis. The research designed a Data Recording Table (DRT) (Murairwa, 2010)that was implemented to collect literature data on the author's names, year and stakeholder categories, types, selection process and analysis levels. A DRT is a research secondary data collection instrument that is designed and tested before collecting the final research data. The researcher records the secondary data on the table. The research reviewed 60related journal articles from literature but collected data from only 45 journal articles for analysis. The 45 journal articles covered the areas that this research was investigating on and these include stakeholder categories, selection process, analysis levels and types. The research also collected primary data through a Survey Monkey from
WhatsApp groups of Harare primary school instructors/teachers and parents/guardians. Therefore, both primary and secondary data were analysed in order to respond to the objectives of this research.

\section{RESULTS AND DISCUSSION}

The research applied Voluntary sampling design (Murairwa, 2015)and thus $100 \%$ of the instructors/teachers and parents completed the questionnaires. Of all the related literature reviewed journal articles, $75 \%$ of them were analysed for this research. The distribution of the respondents by stakeholder and gender is presented in Table 2.T

Table 2: Distribution of Respondents by Status and Gender

\begin{tabular}{|c|c|c|c|}
\hline \multirow{2}{*}{ Stakeholder } & \multicolumn{3}{|c|}{ Gender } \\
\cline { 2 - 4 } & Male & Female & Total \\
\hline Teacher/Instructor & 31.67 & 16.67 & 48.33 \\
\hline Parent & 40.00 & 11.67 & 51.67 \\
\hline Total & 71.67 & 28.33 & 100.00 \\
\hline
\end{tabular}

Table 2 shows that $48.33 \%$ and $51.67 \%$ were teachers/instructors and parents respectively. The difference of two proportions test results are Difference $=3.34 \%, 95 \%$ $\mathrm{CI}=-14.1383 \%$ to $20.5341 \%$, Chi-squared $=0.133, d f=1$ and Significance level $(p)=0.7156($ MedCalc Software Ltd, 2021). Statistically, the equal number of teachers/instructors and parents participated in the research. Table 2 also shows that $71.67 \%$ and $28.33 \%$ were males and females respectively. This means that more males participated in this research. The research assessed the perceptions of the instructors/teachers and parents on the importance of identifying, classifying and engaging the primary school stakeholders and presented the results in Figure 2.

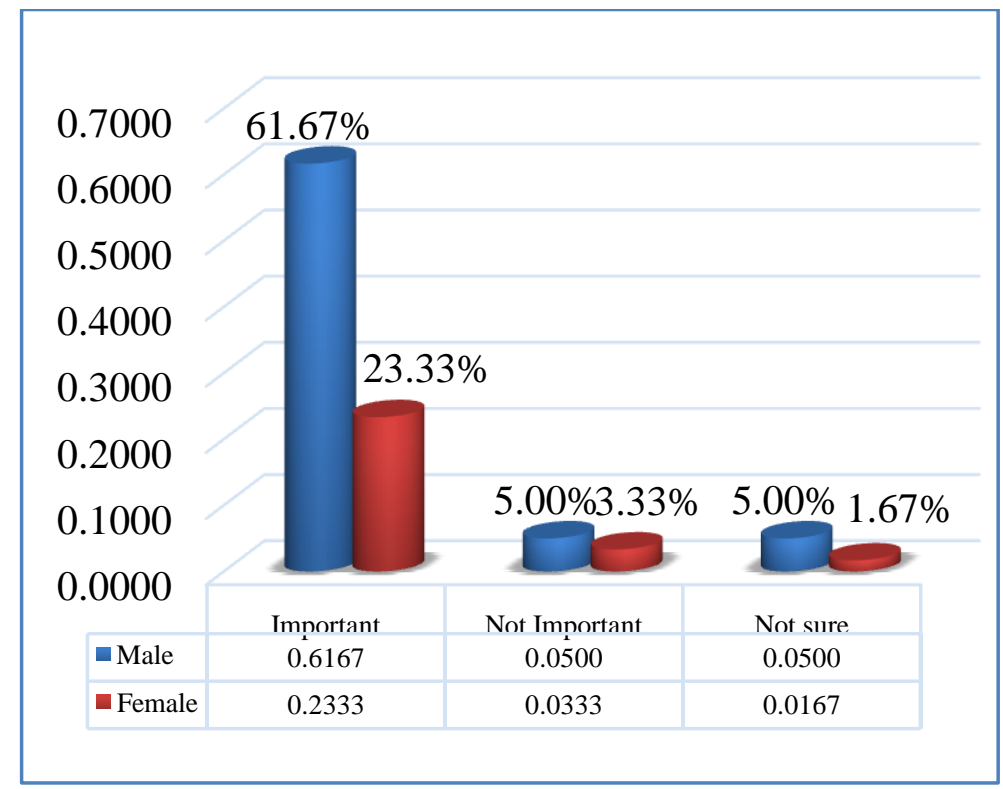

Figure 2: Participants' Perceptions on the Importance of the Primary School Stakeholders 
Figure 2 shows the proportions of the perceptions of the instructors/teachers and parents on the importance of identifying, classifying and engaging the primary school stakeholders. Of all the 60 participants, $85 \%$ agreed that stakeholders' involvement in the running of the primary school is important while $8.33 \%$ stated that their involvement is not important and $6.67 \%$ indicated that they were not sure whether the primary school stakeholders' involvement is important or not. The results indicate that $85 \%$ of the instructors/teachers and parents want to see a good relationship between the primary school and its stakeholders. The results in Figure 2 concur with the results obtained by Franzén, Hammer and Balfors(2015)and Fernandes, Ward, Araújo, Loureiro and Braga(2014)that solid relationship improves the general administration of the primary schools. Sulemana, Musah and Simon(2018) stated that stakeholders should be involved in the implementation, monitoring and evaluation of the primary school activities.

The involvement of the stakeholders in the operations enhances the chance of success through achieving the goals (Magassouba, Tambi, Alkhlaifat, \& Abdullah, 2019) of the primary school. However, a solid relationship with the stakeholders has also challenges that may affect the success of the primary school-stakeholder relationship. UNESCO (2016) stated that stakeholders with physical disabilities may not be able to participate in decision-making because of lack of knowledge and awareness, lack of transport and problems with access to buildings where meetings may be taking place. The management felt that elderly stakeholders may not fully partake in creative and innovative decision making with regards to education because of the agenda, time, duration and accessibility of the meetings. The communities with many languages may prevent others from contributing to decisions that affect education and also lack of time either working (often very long hours) or looking after the family, lack of understanding of the community and voluntary sectors, among many other factors.

Kladifko(2013) highlighted the community level stakeholder challenges for participating in the development and implementation of the District Education Strategic Plan (DESP) to include the fear of district level stakeholders to be accountable, resistance to change, lack of skills in the use of participatory approaches, communication problems and lack of funds to organise participatory activities, time wasting and vast terrain. The research identified the stakeholders of the primary school and presented the results in Table 3.

Table 3: Primary School Stakeholders

\begin{tabular}{|c|c|c|}
\hline $\begin{array}{c}\text { Stakeholder } \\
\text { hers }\end{array}$ & $\% 8$ Score & $\begin{array}{c}\text { Ran } \\
\mathrm{k}\end{array}$ \\
\hline $\begin{array}{c}\text { Instructors/Teac } \\
\text { Learners/Pupils }\end{array}$ & 97 & 2 \\
\hline Parents & 96 & 3 \\
\hline Community & 95 & 4 \\
\hline Administrators & 91 & 5 \\
\hline
\end{tabular}

\begin{tabular}{|c|c|c|}
\hline Stakeholder & $\begin{array}{c}\% \\
\text { Score }\end{array}$ & $\begin{array}{c}\text { Ran } \\
\mathrm{k}\end{array}$ \\
\hline $\begin{array}{c}\text { Advocacy } \\
\text { Bodies }\end{array}$ & 53 & 19 \\
\hline $\begin{array}{c}\text { Policy } \\
\text { Makers }\end{array}$ & 52 & 20 \\
\hline Donors & 52 & 21 \\
\hline Suppliers & 49 & 22 \\
\hline $\begin{array}{c}\text { Financial } \\
\text { Institutions }\end{array}$ & 47 & 23 \\
\hline
\end{tabular}

\begin{tabular}{|c|c|c|} 
Government & 90 & 6 \\
\hline Ministries & 89 & 7 \\
\hline Industry & 85 & 8 \\
\hline Universities & 83 & 9 \\
\hline Colleges & 83 & 10 \\
\hline $\begin{array}{c}\text { Local } \\
\text { Authorities }\end{array}$ & 82 & 11 \\
\hline $\begin{array}{c}\text { Other Primary } \\
\text { Schools }\end{array}$ & 80 & 12 \\
\hline Regulators & 74 & 13 \\
\hline Shareholders & 72 & 14 \\
\hline Farmers & 63 & 15 \\
\hline Subject Experts & 59 & 16 \\
\hline Partners & 58 & 17 \\
\hline Unions & 58 & 18 \\
\hline
\end{tabular}

\begin{tabular}{|c|c|c|} 
Investors & 45 & 24 \\
\hline Sponsors & 44 & 25 \\
\hline $\begin{array}{c}\text { Youth } \\
\text { Organisation } \\
\text { s }\end{array}$ & 40 & 26 \\
\hline Alumni & 38 & 27 \\
\hline $\begin{array}{c}\text { Religious } \\
\text { Groups }\end{array}$ & 32 & 28 \\
\hline $\begin{array}{c}\text { Media } \\
\text { Houses }\end{array}$ & 31 & 29 \\
\hline $\begin{array}{c}\text { Elected } \\
\text { Officials }\end{array}$ & 31 & 30 \\
\hline Business & 22 & 31 \\
\hline NGOs & 17 & 32 \\
\hline Civil Society & 17 & 33 \\
\hline Creditors & 11 & 34 \\
\hline Joint Venture & 11 & 35 \\
\hline Countries & 10 & 36 \\
\hline
\end{tabular}

The respondents were requested to answer a question by ticking what they considered to be the primary school stakeholders. Table 3 shows that the first twelve stakeholders with at least $80 \%$ of the instructors/teachers and parents' percentage scores are important to the day to day running of the primary school activities. Some of the stakeholders in Table 3 can further be grouped into sub-groups, for example, instructors/teachers can be grouped into unionised and private sector instructors/teachers. The Salience model groups the stakeholders into three main groups, namely, power (dormant), legitimacy (discretionary) and urgency (demanding) (Singh, 2021). The results in Table 3 confirm the findings by CIPS(2020), Boyce (2020), WojewnikFilipkowska and Wegrzyn(2019) and Murairwa (2018) on the list of the stakeholders of the school. The list in Table 3covers most important stakeholders of the primary school. However, all the instructors/teachers and parents forgot to listthe researchers as important stakeholders of the primary school. This may be an indication that researchers are not conducting research activities in primary schools. Therefore, the question that may be bothering you now is "Are primary school administrators making evidence based creative and innovative decisions?" However, the question is not addressed in this research but in future study by the researchers. The failure to identify researchers as key primary school stakeholders could be due to the scope of the population from which the sample used was selected. The research investigated the stakeholder analysis and engagement levels and presented the results in Table 4.

Table 4: Primary School Stakeholder Analysis Levels $(n=60)$

\begin{tabular}{|c|c|c|c|}
\hline Measurement & $\%$ Score & Rank & Scale \\
\hline Contribution & 28 & 1 & Low - High \\
\hline Participation & 24 & 2 & Partial - Full \\
\hline Influence & 16 & 3 & Partial - Full \\
\hline Beneficiary & 15 & 4 & Indirect or Direct \\
\hline Engagement & 10 & 5 & Low - High \\
\hline Power & 4 & 6 & Partial - Full \\
\hline Impact & 3 & 7 & Partial - Full \\
\hline
\end{tabular}


Table 4 shows the scale of measurement of each of the identified measurements for analysing and engaging the stakeholders of the primary school. The participants selected Contribution (Low - High) (28\%) and Participation (Partial Full) $(24 \%)$ as the most measurement levels that should be used to determine the value of the stakeholders to the primary school. The other critical stakeholder measurement levels are Influence (Partial - Full) (16\%) and Benefit (Indirect - Direct) (15\%). The results in Table 3 confirm the findings by PHAST (2020) and Compliance Prime(2019) that the stakeholders play important roles for a better future of the primary school. The perceptions of the instructors/teachers and parents to the classification of the stakeholders of the primary school are presented in Figure 3.

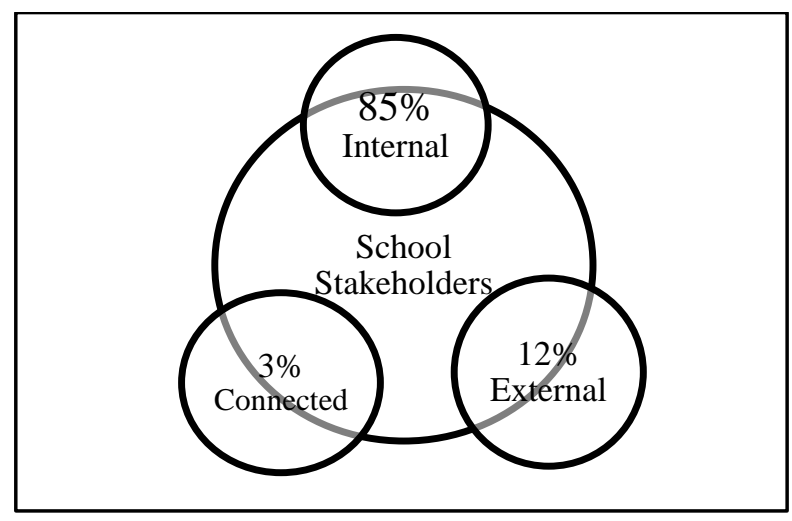

Figure 3: Teachers and Parents'Classification of the Primary School Stakeholders
The instructors/teachers and parents identified three categories of the primary school stakeholders and these are internal $(85 \%)$, external $(12 \%)$ and connected $(3 \%)$ as presented in Figure 3. The results are similar to the findings by Singh(2021), CIPS(2020), Compliance Prime(2019), Surbhi(2017), Hawrysz and Maj(2017) and Mainardes, Alves and Raposo(2013). The data collected from literature and presented in Table 1 above show that $100 \%$ of the articles reviewed from literature identified internal and external as the main groups of the stakeholders of the primary school. Of all the respondents, $85 \%$ stated that the most important group of the primary school stakeholders is the internal group that include administrators, board members, staff members, volunteers, and donors. These results support the findings by Boyce(2020) and Compliance Prime (2019) that the most important stakeholders of the institution are the internal and external groups. The research developed a framework for analysing, classifying and engaging primary school stakeholders from literature data and the results obtained from the analysed data and presented the findings in Figure 4.

Stakeholder Identification, classification and Engagement (SICE) framework

The research developed the process of identifying, classifying and engaging the stakeholders of the primary school. The process for Identifying, Classifying and Engaging(ICE) the stakeholders of the primary school is presented in Figure 4.

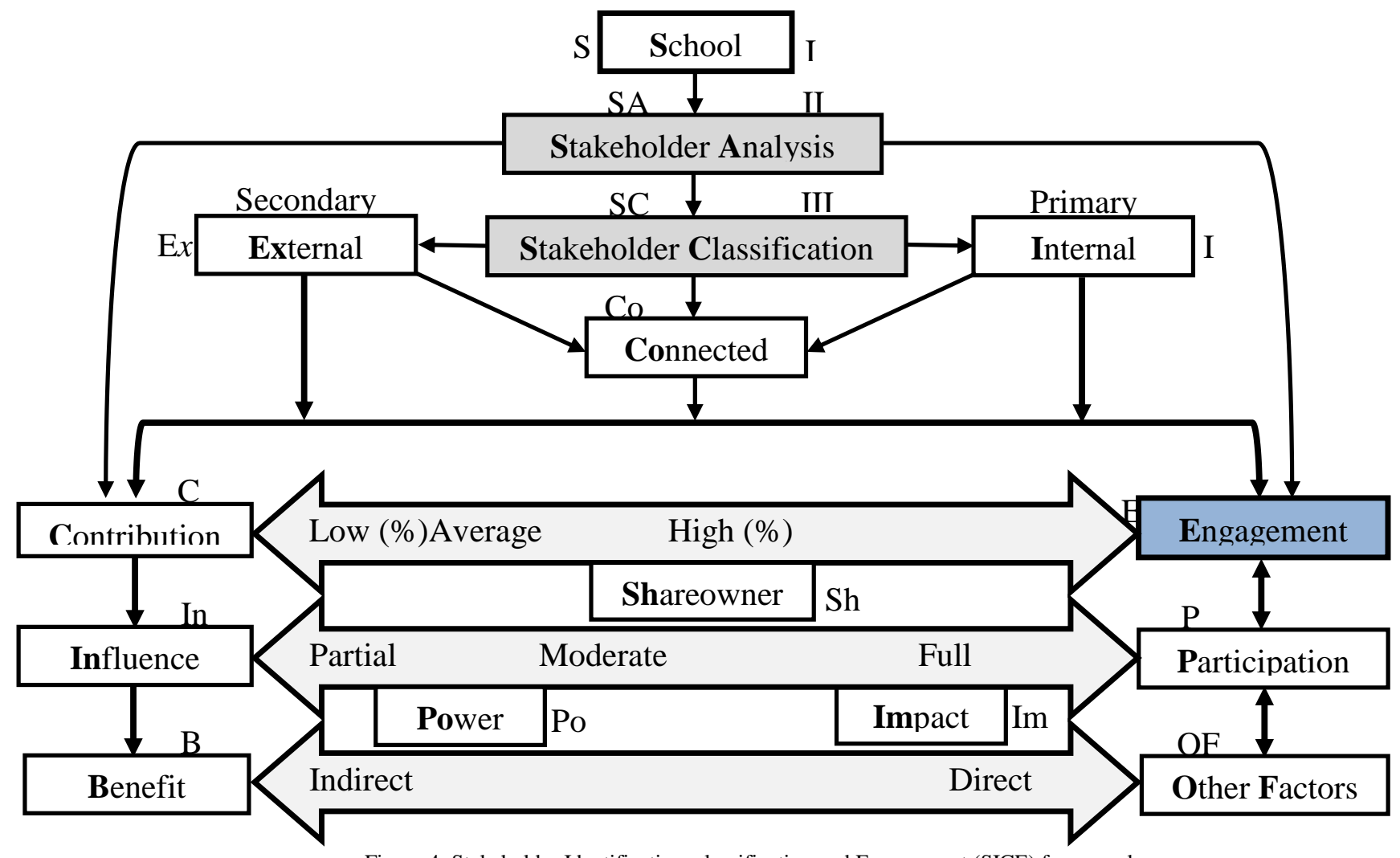

Figure 4: Stakeholder Identification, classification and Engagement (SICE) framework 
The primary school SICE frame work in Figure 4shows the stages that should be implemented in order to identify, classify and engage (ICE)the stakeholders of the primary school. As stated by Murairwa(2018) and Mainardes, Alves and Raposo (2013), the primary school stakeholders are many and varied in type as shown in the SICE framework. The reverse arrows provide an opportunity for the primary school administrator who has reached an unsatisfactory engagement decision to enhance it through further stakeholder analysis. The employer is a critical stakeholder to the primary school. The primary schoolstakeholders should participate fully in the education strategic plan. The stages of the SICE are

Stage I - Primary School: This is a primary school that is in the process of identifying its stakeholders in order to improve the quality of its learning processes. The primary school should identify all the suppliers, inputs, conversion processes, outputs and customers for stakeholder analysis.

Stage II - Stakeholder Analysis: This is a process whereby the primary school identifies its stakeholders of each of its learning system components and group them according to the level of contribution, interest, influence, participation and other factors to the whole education process.

Stage III - Stakeholder Classification: This is the process of distributing stakeholders into distinctive groups. The primary school stakeholders can be grouped into three main groups, namely, internal, external and connected groups. The internal stakeholders are people within the primary school and they include learners/pupils, staff members, administrators and owners. These are often referred to as primary stakeholders (Fassin, 2012; Clarkson, 1995) and often enjoy the direct relationship (Fassin, 2012)with the primary school. The external stakeholders are people who are not within the primary school but who are affected by its performance and they include unions, sponsor, customers, suppliers, local authorities and government agencies, among others. According to Pinheiro(2015), the participation of external stakeholders in the learning processes has become prominent. The primary school should identify its internal and external stakeholders (Hawrysz \& Maj, 2017; Surbhi, 2017; CIPS, 2020)for enhancing the quality of the creative and innovative decisions that are made by its administrators. The third group is of those with stakes in the primary school and they are known as the Connected stakeholders. The model in Figure 4shows that the external, internal and connected primary school stakeholders can further is grouped by the level of contribution, influence (of individual, group or primary school), benefit and participation. Figure 4 shows that the primary school stakeholder engagement can be through contribution, influence, benefit, shares owned, power, impact and participation, among other factors. Thus, a number of stakeholder engagement models can be extracted from the SICE framework for implementation. The tree diagram for extracting the engagement models from the SICE framework is presented in Figure 5.

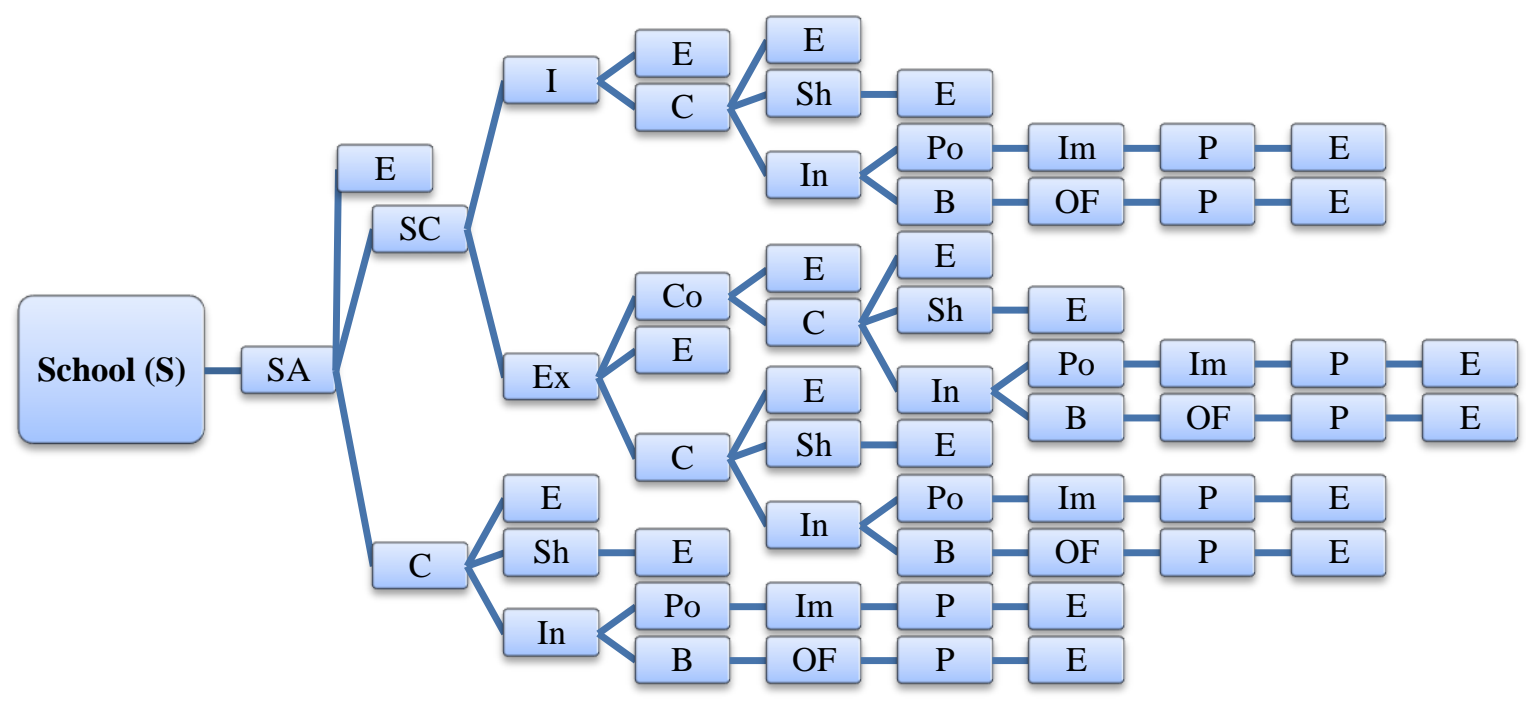

Figure 5: Tree Diagram of the SICE Framework

In Figure 5, the Engagement (E) is the termination point of the process of extracting engagement models from the SICE framework. For example, the primary school administrator who intends to exhaustively identify, classify and engage all stakeholders must in the process of implementing the whole SICE tree apply the SSASCExCoCInBOFPE model. Thus, the Primary School (S) administrator conducts stakeholder
Analysis (SA) and Stakeholder Classification (SC), considers Connected (Co) group and assesses the Contribution (C), Influence (In), Benefits (B), Other Factors (OF) and Participation (P) levels in order to Engage (E) the stakeholders. The primary school administrator must implement the whole tree in order to identify, classify and 


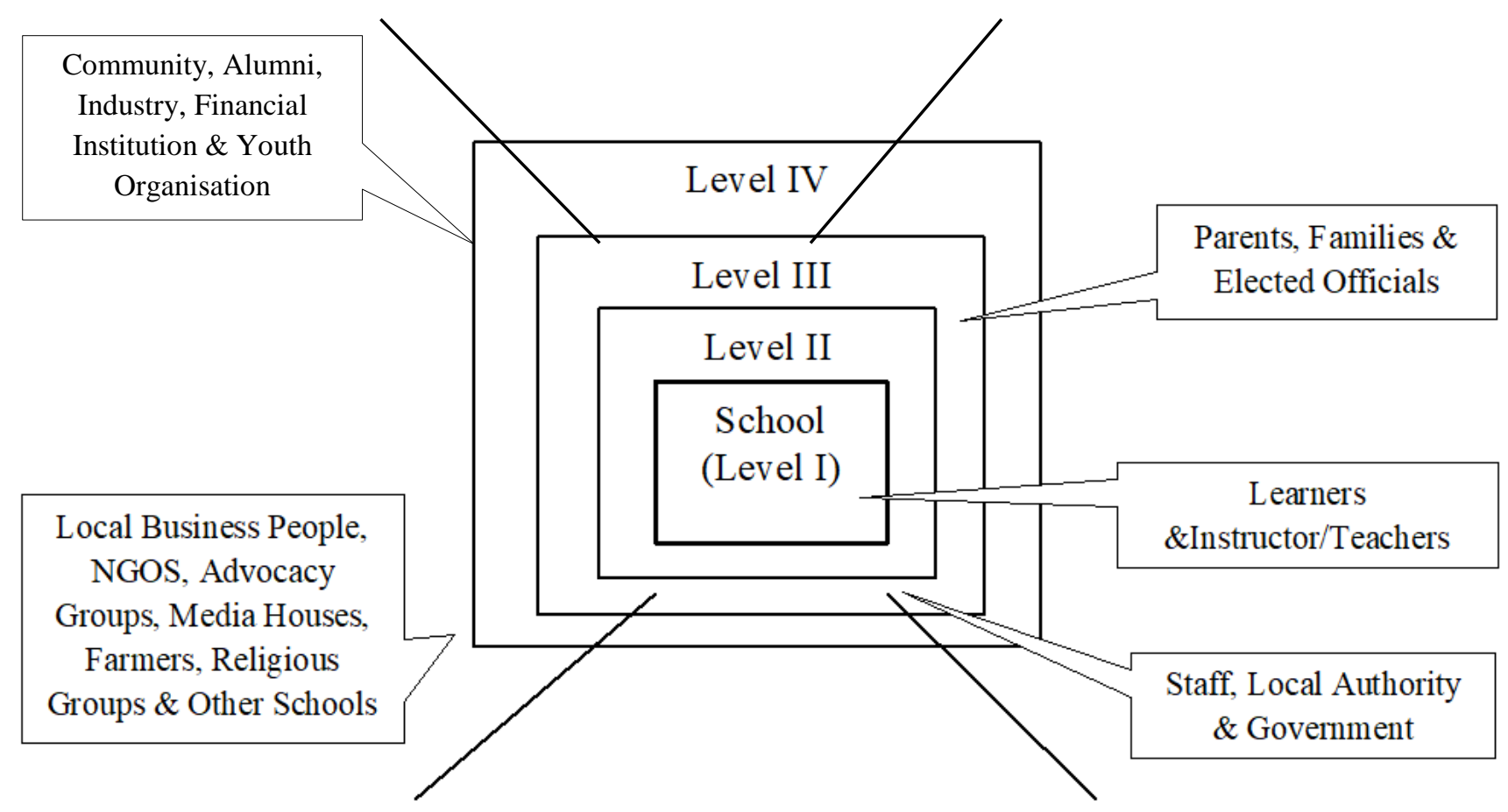

Figure 5: Primary School Stakeholder Engagement (SSE)Model

The SSE model covers three main concerns of the researchers and these are analysis, identification and classification of the primary school stakeholders. Figure 5 shows the contribution of each category of the primary school stakeholders. The stakeholders can be categorised into five main groups according to their contribution to the achievement of the primary school objectives and these stakeholder group levels are core (I), direct support (II), indirect support (III), general support (IV) and general (V). These primary school stakeholder groups are briefly discussed henceforth.

\section{Level I: Core Stakeholders (Primary School) (CS)}

The group consists of the major stakeholders of the primary school. This is made up of the learners and instructors/teachers of the primary school. The interaction of the groups of the core stakeholders through the learning processes establishes a standard primary school. Thus without the CS group, there is no primary school to talk about.

\section{Level II: Direct Support Stakeholders (DSS)}

The group is made up of immediate support employees and organisations such as staff members, researchers, regulatory authorities, universities, government, education ministry and local authority. The DSS group supports the operations of the primary school (core stakeholders - CS). The DSS group participates in the development of the primary school curriculum.

\section{Level III: Indirect Support Stakeholders (ISS)}

The group includes parents, families, elected officials and others. The stakeholders have an indirect bearing on the quality of the administration of the primary school. The ISS group supports the operations of the primary school by making sure that their children attend lessons without disruptions. The ISS group provides learners/pupils for the primary school. The ISS group may be involved in curriculum development or not depending on the subject being discussed by the primary school.

\section{Level IV: General Support Stakeholders (GSS)}

The GSS group includes local business people, community, alumni, industry, financial institutions and youth organisations, among others. The GSS group supports the beginning of the primary school learning systems. The GSS group makes sure that a primary school with acceptable standard learning processes is established in the community.

\section{Level V: General Stakeholders (GS)}

The GS group includes non-governmental organisations, advocacy groups, media houses, farmers, religious groups and other primary schools, among others. The GS is minimally 
affected by the operations of the primary schools. The group may also participate in the establishment of the primary school in the community.

The success of the primary school is determined by the level of identification, classification and engagement (ICE) of its stakeholders. Therefore, it is imperative for the primary school administrators to carefully analyse and classify their stakeholders. It is prudent that highly qualified and competence primary school administrators are appointed in positions that deal with the analysis, classification and engagement of the stakeholders.

\section{CONCLUSION AND RECOMMENDATIONS}

The primary school stakeholders include community, unionised and private instructors/teachers, parents, learners/pupils, non-governmental organisations, administrators, sponsors, suppliers, elected officials, advocacy and pressure bodies, financial institutions, media houses, farmers, religious groups, local authorities, regulators, investors, government, universities, colleges, unions, civil society, business industry, youth organisations, subject experts, ministries, shareholders, creditors, policy makers, joint venture partners, countries, donors, alumni, researchers and other primary schools. These primary school stakeholders can be grouped into three distinctive categories and these are internal, external and connected groups. However, most of the studies in literature have identified internal and external as the main groups of the primary school stakeholders. It was clearly articulated that the primary school stakeholder identification, classification and engagement (SICE) model will propel the education development, instruction improvement, increased education access and enhancement of instructor/teacher skills. The primary schools should implement the SICE framework and the primary School Stakeholder Engagement(SSE)model in order to improve the quality of creative and innovative decisions being implemented.

\section{SCOPE FOR FURTHER STUDIES}

There is need to assess whether administrators are making evidence based creative and innovative decisions in Harare primary schools. This could assist to establish the level of research activities and level of quality of decisions being implemented in Harare primary schools.

\section{ACKNOWLEDGEMENT}

The researchers wish to thank the primary school stakeholders especially the instructors/teachers and parents who participated in the data collection that led to the writing of this journal article.

\section{REFERENCES}

[1] Aapaoja, A., \& Haapasalo, H. (2014). A Framework for Stakeholder Identification and Classification in Construction Projects. Open Journal of Business and Management, 2, 43 - 55. Retrieved from http://dx.doi.org/10.4236/ojbm.2014.21007

[2] Abubakari, A., \& Al-hassan, S. (2016). Assessing the contribution of stakeholders to basic education service in Zongo communities in Brong Ahafo Region, Ghana. UDS International Journal of $\begin{array}{lrr}\text { Development, } & 3(1), & 51 \\ \text { doi https://doi org/10.47740/99.UDSJD6i }\end{array}$

65.

[3] Alves, H., Mainardes, W. E., \& Raposo, M. (2010). A Relationship Approach to Higher Education Institution Stakeholders Management. Tertiary Education and Management, $16,159-181$.

[4] Baker, D. (2018, November 9). 14 Signs of a solid relationship. Retrieved June 13, 2020, from https://brightfreak.com/signs-of-asolid-relationship/

[5] Benneworth, P., \& Osborne, M. (2015). Understanding universities and entrepreneurship education. CHEPS-CRADALL Working Paper CHEPS 08/2015 (pp. 1 - 26). Glasgow: CHEPS: Enschede(NL) and CR\&DALL.

[6] BeWater. (2017, March). Stakeholder Selection. Retrieved from BeWater: Sociaty Adapting to Global Change: http://www.bewaterproject.eu/bewater-approach/stakeholderselection

[7] Boyce, P. (2020, September 20). Stakeholder Definition. Retrieved from Boyce Wire: https://boycewire.com/stakeholder-definition/

[8] Byerengo, V. P., \& Onyango, D. O. (2021). chool-FamilyCommunity Partnerships and Their Influence on Student Achievement in Public Secondary Schools in Ilemela Municipality, Tanzania. In F. Nafukho, \& A. B. Makulilo (Eds.), Handbook of Research on Nurturing Industrial Economy for Africa's Development (pp. 357 - 379). IGI Global. doi:10.4018/978-1-7998-6471-4.ch019

[9] Christenson, H. (2005). Community involvement for school development. New York, USA: Thousand Oaks.

[10] CIPS. (2020). Internal, External and Connected Stakeholders. Chartered Institute of Procurement \& Supply. Retrieved May 7, 2021, from https://www.cips.org/PageFiles/156828/Internal\%20external\%20a nd\%20connected\%20stakeholders.pdf

[11] Clarkson, M. (1995). A stakeholder framework for analyzing and evaluating corporate social performance. Academy of Management Review, 20(1), 92 - 117. doi:10.2307/258888

[12] Compliance Prime. (2019, October 17). Role of Stakeholders in Business Organization. Retrieved from Compliance Prime: Role of Stakeholders in Business Organization

[13] Deloitte \& Touche. (2014). Stakeholder Engagement. Johannesburg: Creative Services at Deloitte

[14] Donaldson, T., \& Preston, E. L. (1995). The Stakeholder Theory of the Corporation: Concepts, Evidence, and Implications. The Academy of Management Review, 20(1), 65 - 91. doi:doi.org/10.2307/258887

[15] Epstein, J., Sanders, G. M., Salinas, C. K., Jansorn, R. N., \& Van Voorhis, L. F. (2002). School, Family and Community Partnerships (2nd ed.). California: Corwin Press, Inc. Retrieved from https://www.govinfo.gov/content/pkg/ERICED467082/pdf/ERIC-ED467082.pdf

[16] Fasan, M., \& Mio, C. (2017). Fostering stakeholder engagement: The role of materiality disclosure in integrated reporting. Business Strategy and the Environment, 26(3), 288 - 305. doi:10.1002/bse. 1917

[17] Fassin, Y. (2012). The stakeholder model refined. Business Ethics, 84(1), 13 - 135. doi:10.1007/s10551-012-1381-8

[18] Fernandes, G., Ward, S., Araújo, M., Loureiro, I., \& Braga, A. (2014). Perceptions of Different Stakeholders on Improving and Embedding Project Management Practice in Organisations. $\begin{array}{lllll}\text { Procedia } & \text { Technology, } & 16, & 957 \quad & -\end{array}$ doi:10.1016/j.protcy.2014.10.049

[19] Franzén, F., Hammer, M., \& Balfors, B. (2015). Institutional development for stakeholder participation in local watermanagement - An analysis of two Swedish catchments. Land Use Policy, 43, 217 - 227. doi:10.1016/j.landusepol.2014.11.013

[20] Freeman, E. R. (1984). Strategic management: A stakeholder approach. Marshfield, MA: Pitman Publishing Inc.

[21] Freeman, K. (2010). The importance of stakeholders in school development. New York, England: Sage.

[22] Green, B. N., Johnson, C. D., \& Adams, A. (2006). Writing narrative literature reviews for peer-reviewed journals: secrets of 
the trade. Journal of chiropractic medicine, 5(3), $101-117$. doi:10.1016/S0899-3467(07)60142-6

[23] Gudavajhala, S. (2017, February 12). Top 5 Stakeholder Analysis Techniques in Projects | Stakeholder Analysis in Project Management. Retrieved May 7, 2021, from Master of Project Academy:https://masterofproject.com/blog/7514/top-5-

stakeholders-analysis-techniques-in-projects-stakeholder-analysisin-project-management

[24] Hawrysz, L., \& Maj, J. (2017). Identification of Stakeholders of Public Interest Organisations. Sustainability, 1 - 13. doi:10.3390/su9091609

[25] Hujainah, F., Bakar, R., Al-haimi, B., \& Abdulgabber, A. M. (2018). Stakeholder quantification and prioritisation research: A systematic literature review. Information and Software Technology, 102, 85 - 99. doi:10.1016/j.infsof.2018.05.008

[26] Huntley, J. (2021). Stakeholder Engagement and the Recruitment Process. Retrieved from Optimum Talent: https://optimumtalent.com/how-stakeholder-engagement-canimpact-improve-and-enrich-the-recruitment-process/

[27] Jones, T. M., \& Wicks, A. C. (1999). Convergent Stakeholder Theory. The Academy of Management Review, 24(2), 206 - 221.

[28] Khanyile, M., \& Green, P. (2016). Application of Stakeholder Management for Business Sustainability in the Higher Education Sector. International Journal of Education Science, 15(3), 328 337.

[29] Kladifko, E. R. (2013). Practical School Community Partnerships Leading to Successful Educational Leaders. Educational Leadership and Administration: Teaching and Program Development, 24, 54 - 61.

[30] Land, M., Macura, B., Bernes, C., \& Johansson, S. (2017). A fvestep approach for stakeholder engagement in prioritisation and planning of environmental evidence syntheses. Environmental Evidence, 6(25), 1 - 7. doi:10.1186/s13750-017-0104-0

[31] Liang, X., Yu, T., \& Guo, L. (2017). Understanding Stakeholders' Influence on Project Success with a New SNA Method: A Case Study of the Green Retrofit in China. Sustainability, 9(1927), 1 19. doi:10.3390/su9101927

[32] Lienert, J. (2020). Explore Perspectives. Retrieved 2020, from SSWM.

[33] Lim, J. S., \& Greenwood, C. A. (2017). Communicating corporate social responsibility: Stakeholder responsiveness and engagement strategy to achieve CSR goals. Public Relations Review, 4, 768 776. doi:10.1016/j.pubrev.2017.06.007

[34] Magassouba, S. M., Tambi, A. M., Alkhlaifat, B. I., \& Abdullah, A. A. (2019). Influence of Stakeholders Involvement on Development Project Performance in Guinea. International Journal of Academic Research in Business and Social Sciences, 9(1), 1111 -1120 .

[35] Mainardes, W. E., Alves, H., \& Raposo, M. (2010). An Exploratory Research on the Stakeholders of University. Journal of Management and Strategy, 10(1), 76 - 88.

[36] Mainardes, W. E., Alves, H., \& Raposo, M. (2012). A model for stakeholder classification and stakeholder relationships. Management Decision, 50(10), $1861 \quad$ - 1879. doi:10.1108/00251741211279648

[37] Mainardes, W. E., Alves, H., \& Raposo, M. (2013). Identifying Stakeholders in a Portuguese university: a case study. Revista de Educación, 2013(362), 429 - 457. doi:10.4438/1988-592X-RE2012-362-167

[38] Mainardes, W. E., Raposo, M., \& Alves, H. (2012). Public university students' expectations: an empirical study based on the stakeholders theory. Transylvanian Re-view of Administrative Science, 2012(35), 173 - 196.

[39] Maric, I. (2013). Stakeholder analysis of higher education institutions. Interdiscipli-nary Description of Complex Systems, 11(2), 217 - 226.

[40] McDonald, J. (2016). Business \& Finance - Strategy. Retrieved 2020, from Business2Community: https://www.business2community.com/strategy/stakeholderidentification-analysis-made-easy-project-managers-01440041
[41] MedCalc Software Ltd. (2021, December 28). Comparison of proportions calculator. Retrieved from MedCalc: https://www.medcalc.org/calc/comparison_of_proportions.php

[42] Mendelow, A. L. (1981). Environmental Scanning - The Impact of the Stakeholder Concept. Internaioonal Conference on Information Systems 1981 Proceedings.20, pp. 407 - 418. AIS eLibrary.

[43] Milosevic, D., Donaldson, T., \& Preston, E. L. (2019). The stakeholder theory of the corporation: Concepts, evidence, and implications. The Academy of Management Review, 65 - 68.

[44] Miroiu, A., \& Andreescu, L. (2010). Goals and Instruments of Diversification in Higher Education. Quality Assurance Review, 2(2), 89 - 101.

[45] Mishra, A., \& Mishra, D. (2013). Descriptive , Instrumental , and Normative Views of Stakeholder Theory. Retrieved from Semantic https://www.semanticscholar.org/paper/Descriptive-\%2CInstrumental-\%2C-and-Normative-Views-of-MishraMishra/c25f506a9af9ffb00f5b66cf2e8565f74e4687ce

[46] Murairwa, S. (2010). A Hybrid Heuristic Research Framework: The Travelling Salesperson Problem. PhD Thesis, Universiti Utara Malaysia (UUM), Kedah.

[47] Murairwa, S. (2015). Voluntary Sampling Design. International Journal of Advanced Research in Management and Social Sciences, 4(2), 185 - $200 . \quad$ Retrieved from http://www.garph.co.uk/IJARMSS/Feb2015/18.pdf

[48] Murairwa, S. (2018). Re-engineering the Education Systems: A Continuous Education Quality Improvement Framework. Mauritius: LAP LAMBERT Academic Publishing. Retrieved from https://www.morebooks.de/store/gb/book/re-engineering-theeducation-systems/isbn/978-613-9-91916-1

[49] Nyatuka, B. O. (2020). Family-Community-Higher Education Partnership: A Critical Pillar in Realizing Social Justice. In J. Keengwe (Ed.), Handbook of Research on Diversity and Social Justice in Higher Education (pp. 129 - 148). IGI Global. doi:10.4018/978-1-7998-5268-1.ch008

[50] OECD. (2017). In-Depth Analysis of the Labour Market Relevance and Outcomes of Higher Education Systems: Analytical Framework and Country Practices Report, Enhancing Higher Education System Performance. Paris: OECD. Retrieved December 29, 2021, from https://www.oecd.org/education/skillsbeyond-school/LMRO\%20Report.pdf

[51] Oleksiv, I., \& Shpak, N. (2012). Method for Selection of Company Stakeholders. ECONTECHMOD. An international quarterly journal, 1(3), $65-74$. Retrieved from https://yadda.icm.edu.pl/baztech/element/bwmeta1.element.baztec h-b6f31088-5b6b-4940-a312-b07383cd925a/c/Oleksiv.pdf

[52] Paine, S. (2009). Engaging Stakeholders. Sustainability Series. Retrieved October 11, 2021, from https://www2.ed.gov/programs/readingfirst/support/stakeholderlor es.pdf

[53] Parmar, L. B., Freeman, E. R., Harrison, S. J., Wicks, C. A., de Colle, S., \& Purnell, L. (2010). Stakeholder Theory: The State of the Art. The Academy of Management Annals, 1 - 62 . doi:10.1080/19416520.2010.495581

[54] PHAST. (2020). Identifying and managing internal and external stakeholder interests. Retrieved from Health Knowledge: Education, CPD and Revalidation from PHAST: https://www.healthknowledge.org.uk/public-healthtextbook/organisation-management/5b-understandingofs/managing-internal-external-stakeholders

[55] Pinheiro, R. (2015). The Role of Internal and External Stakeholders. doi:10.1007/978-94-017-9570-8_3

[56] Product Plan. (2020). https://www.productplan.com/. Retrieved 2020, from https://www.productplan.com/.

[57] Rawley, D. (1997). The school and community relations. MA, Needham Heights: Allyn \& Bacon.

[58] Schmeer, K. (2016). Stakeholder Analysis Guidelines. Retrieved October 14, 2021, from https://www.who.int/workforcealliance/knowledge/toolkit/33.pdf

[59] Schwartzman, S., Pinheiro, R., \& Pillay, P. (2015). Higher Education in the BRICS Countries: Investigating the Pact between Higher Education and Society. New York: Springer. 
[60] Seres, L., Tumbas, P., Maric, M., \& Pavlicevic, V. (2019). University Stakeholder Mapping. Research Gate.

[61] Sheridan, S. M. (2013). Families and Schools in Partnership: Creating Connections for Student Success. Educational (School) Psychology \& Nebraska Research Alliance on Children, Youth, Families and Schools. Lincoln.

[62] Singh, H. (2021, August 5). The Salience Model for Stakeholder Classification. Retrieved from Deep Fried Brain: https://www.deepfriedbrainproject.com/2017/09/salience-modelfor-stakeholder-classification.html

[63] Slaba, M. (2015). Stakeholder Groups of Public and Private Universities in the Czech Republic - Identification, Categorization and Prioritization. Review of Economic Perspectives, 15(3), 305 326. doi:10.1515/revecp-2015-0022

[64] Strand, R., \& Freeman, R. E. (2015). Scandinavian cooperative advantage: The theory and practice of stakeholder engagement in Scandinavia. Business Ethic, 127(1), 65 - 85. doi:10.1007/s10551013-1792-1

[65] Sulemana, M., Musah, B. A., \& Simon, K. K. (2018). Evaluation of District Assembly Projects and Programmes in the SaveluguNanton Municipality Assembly, Ghana. Ghana Journal of Development Studies, 15(1), 173 - 195. doi:10.4314/gjds.v15i1.9

[66] Surbhi, S. (2017, April 28). Difference Between Internal and External Stakeholders. Retrieved from Key Differences: https://keydifferences.com/difference-between-internal-andexternal-stakeholders.html

[67] UNESCO. (2016). Community Participation in School Development Programmes. UNESCO.

[68] UNESCO. (2017). Definitions and classifications of the OECD international education statistics. UNESCO. Retrieved October 12, 2021, from https://www.oecd-ilibrary.org/definitions-andclassificationsof-the-oecd-international-educationstatistics_5jfnt22410xw.pdf

[69] UpCounsel. (2021). Advantages and Disadvantages of Stakeholder Theory. Retrieved from UpCounsel https://www.upcounsel.com/advantages-and-disadvantages-ofstakeholder-theory

[70] Venturelli, A., Cosma, S., \& Leopizzi, R. (2018). Stakeholder engagement: An evaluation of European banks. Corporate Social Responsibility and Environmental Management, 25(4), $690-703$. doi:10.1002/csr.1486

[71] Williams, A. S. (2017). Effective Stakeholder Management Strategies for. Walden University.

[72] Wojewnik-Filipkowska, A., \& Wegrzyn, J. (2019). Understanding of Public-Private Partnership Stakeholders as a Condition of Sustainable Development. Sustainability, 11(1194), 1 - 16. 